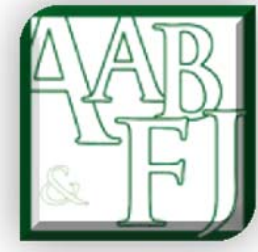

\title{
Editorial Volume 7 Issue 4
}

Ciorstan Smark ${ }^{1}$, Greg Laing² \& Ron Perrin ${ }^{3}$,

The articles published in this issue of AABFJ are drawn from the accounting discipline.

Topics covered in this issue include auditing, financial reporting and management accounting.

On the broad topic of auditing, Kuar and van der Laan (2013) review the implications of the Westpac Banking Corporation and 789TEN Pty Ltd case as regards representation letters from lawyers for auditors and policy makers. From Jordan, Hamdan, Mushtaha and Al-Sartawi (2013) investigate the relationship audit committee characteristics and earnings management in companies listed on the Amman stock exchange.

From issues involving reporting and public accountability, Boolaky, Krishnamurti and Hoque (2013) examine the role of environmental factors that influence a country's strength of auditing and reporting standards. Capalbo and Palumbo (2013) explore the public accountability (via financial reporting requirements) of Italian State Owned Enterprises. Also from a public sector perspective, Mir and Sutiyono (2013) note the significant increase in qualified audit reports arising from recent Indonesian local government reporting reforms.

Rooney (2013) reflects on three theoretical frameworks developed to explain management control design in inter-organisational collaborations and suggests resultant opportunities to consolidate extant management accounting theories arising from these frameworks.

On an administrative front, $\mathrm{AABFJ}$ has closed to further submissions until the end of 2014 because of the long lead time of articles already accepted in AABFJ through to 2015 and our desire to keep our content fresh and relevant.

\footnotetext{
${ }^{1}$ University of Wollongong, Australia

${ }^{2}$ University of the Sunshine Coast, Australia GLaing@usc.edu.au

${ }^{3}$ University of Wollongong, Australia
} 
Smark, Laing \& Perrin: Editorial 